\title{
The Structural Market Shift Review of Lesotho: Transitory Situational Analytic Market Policy Introspection for Sustainable Development
}

\author{
Moses M. M. Daemane \\ National University of Lesotho, Lesotho \\ mosesdaemane@gmail.com
}

\begin{abstract}
This paper analyzes Lesotho's agricultural market in both state-regulated and liberalized policy. It identifies institutional constraints inhibiting efficient marketing in both policy systems. Realization of such constraints constitutes an analytic illumination on the formulation of strategies for poverty alleviation and sustainable development through agricultural marketing as the main sector with $86 \%$ of Lesotho's poor subsistence producers. This desk-study comprehends the state and the market as imperfect institutions in sustainable development and alleviating poverty by unearthing constraints to pre and post agricultural market reforms in Lesotho. It thus examines Lesotho's agricultural market transitory situational analysis and organization, providing empowering lessons in poverty reduction and sustainable development at grassroots level. Forms of state intervention before market reform, market reform process and progress and the institutional constraints and implications in poverty reduction and sustainable development are covered to attain critical lessons as cognitive knowledge applicable in empowering the poor in crops production, food security and sustainable development. State and the market and their active interaction have globally been believed to be institutional agencies with the main role of distributing resources towards poverty reduction and sustainable development but their imperfections and constraints hampering effectiveness and efficiency of such a role still lack adequate contextual review to effectively increase productivity and enrich lives of the poor agricultural producers, particularly in Lesotho.
\end{abstract}

Keywords: Agricultural marketing, institutional constraints, liberalized market, market imperfections and state imperfections, sustainable development

\section{Introduction}

This paper analyzes Lesotho agricultural market structure in both state and liberalized (Free Trade) policy system. It identifies institutional and policy constraints that have inhibited efficient marketing in both situations and therefore poverty reduction and sustainable development strategies. Recognizing these constraints sheds light on both strategic options for agricultural marketing/trading as the main sector in which most of the Lesotho poor are involved. The paper provides an analysis of the generic marketing organization of crops produce in Lesotho. Constraints to non-liberalized and liberalized marketing form preeminence in this analytic discourse. A guiding question is; what are the political institutional and economic policy constraints that hamper non-liberalized and liberalized agricultural marketing and what are their implications serving as lessons in poverty alleviation and sustainable development in the agricultural market. The paper argues and assumes that there are institutional and economic policy imperfections in both regulated and liberalized markets/free trade but most importantly, furthermore, large-scale monopolies suppress individual private sector development efforts in both regulated and deregulated markets and as such the market may never be efficient and effective in inducing sustainable development and reducing poverty of the poor and weak subsistence producers through its transactionery distribution of income, goods and services and socio-economic entitlements and opportunities.

Pre-liberalization or non-free trade refers to state-led agricultural market era before 1995 privatization. During intervention/regulation, government of Lesotho (GOL) since 1966 provided various resources and subsidy in crops and livestock production, marketing, processing and service provision through state-led enterprises. However, trade losses due to supplying below production costs, poor management, corruption, and suppression of private sector's growth and profitability justified privatization of such enterprises to reverse the situation through liberalization/free trade policy entailing deregulation and privatization. 
International Monetary Fund/IMF and World Bank enforced this as financial lending conditionality. The policy was known as Structural Adjustments Programs (SAPs). Though, SAPs was officially declared in 1995, actual gradual implementation in various sectors is traceable from 1985. While liberalization may have its potentials, in the local context it lacked explicit improvement objectives for poor peasants, the majority population and was hence limited (GOL, Technical Report M, 1999). The paper's structure is as follows; after this introductory part, there is a review of the state intervention/agricultural market regulation and deregulation interlaced with the constraints requiring expository analysis if the agricultural market is to induce sustainable development and reduce poverty of the weak producers either in the regulatory or deregulatory era. System and description analysis, extrapolations, simulation, excerption and constructive data 'collapsing' form research methods for this paper.

\section{Literature Review}

Review of Lesotho Agricultural Market Intervention Prior 1995 Liberalization: GOL used to regulate agricultural marketing significantly. There was direct government involvement in production, pricing, marketing and processing of agricultural commodities. Production was highly subsidized and there was provision of agricultural services and inputs to peasants. GOL controlled marketing and production of agricultural commodities for many decades since 1965 political independence from Britain mainly through Co-op Lesotho Ltd (used to be the apex of the cooperative movement in Lesotho) and large-scale mills for cereals (Lesotho Flour Mills and Maseru Roller Mills). This was also generally done through parastatal organizations, government enterprises and government service sectors under great subsidies. Major objectives of this market interference by GOL included protecting farmers from exploitation by foreign traders and transforming of agricultural productivity. However, organizational institutional and financial government policy constraints such as the 'red tape', financial regulations combined with poor managerial skills across sectors directly inhibited commercial trading policies of profit making and sustainability in enterprises. The problematic effects seen under this old public management therefore included difficulty in cost recoupment, inept and poor implementation, and inefficient market information dissemination combined with recorded apparent motivation failures and rent-seeking (ASIP, 1997, see Ellis, 1992:12). This poor performance of GOL run agricultural enterprises confirms 'real' rather than 'abstract' markets perspective which may be reflected by this statement; "The recognition of the general imperfection of (liberalized) markets does not imply, however, that governments can necessarily do better. Economics has recognized that governments are also imperfect institutions and that such imperfect institutions need to be understood". Analytic inference of above situation may be shown diagrammatically as below;

Figure 1: GoL Pre-Liberalization Market Intervention Extent

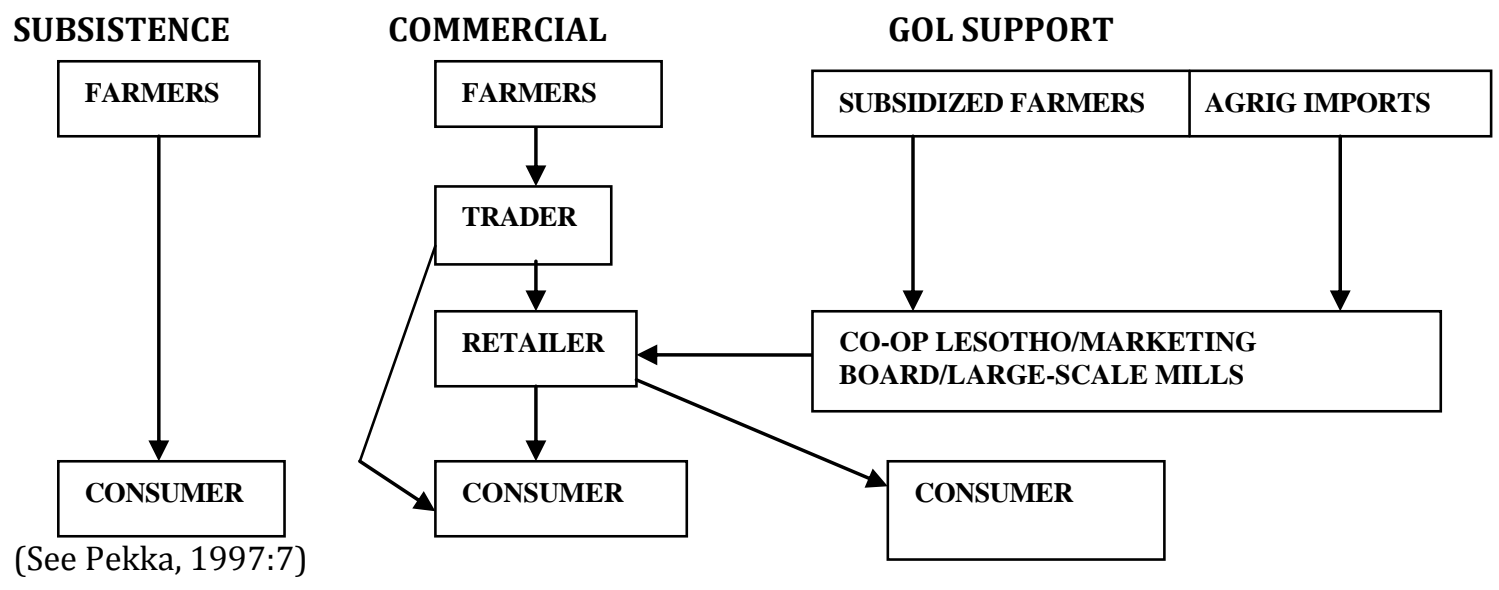

Subsidized peasants countrywide were provided with transport to bring their cereals to large-scale mills and Co-op, which paid them at fixed prices and redistributed to market outlets at controlled prices. Any cereal producer could bring produce to market through these institutions. However, for livestock, 'Livestock Products Marketing Services'/LPMS and 'National Abattoir and Feedlot Complex'/NAFC replaced Co-op and 
large-scale mills. These institutions used to be under absolute GOL control and ownership until 1995. Though LPMS privatization process is delayed, Co-op is closed from reported mismanagement and collapse, largescale mills and NAFC are now privatized (Lehohla, Lebusa, Lenka, Moteane, Lethunya and Mohau, 1993).

\section{Liberalization Market Policy Process and Progress}

In response to the poor performance of GOL controlled enterprises, the 1995 Privatization Act established Privatization Unit under the Ministry of finance. The Unit has now spent US\$11 million sponsored by GOL and World Bank. The Unit's responsibility is to act on behalf of the government in coordinating and affecting the process of preparing state owned enterprises for privatization. State owned enterprises and services are sold to the private sector with market forces. Therefore, the actual privatization process involves the line Ministry, Privatization Unit, cabinet and 'private traders' who are sometimes RSA (Republic of South Africa) driven though it is legally declared that they should partly be Lesotho citizenship. Actual transfer of assets or leases may involve legal practitioners, credit institutions and Lands Department (GOL, 1999). Deregulation was adopted to cultivate a conducive environment for this commercial policy to work. This was meant to facilitate participation and development of the private sector in agricultural sector and enable efficient allocation of resources in most benefiting sectors. The hope was to achieve competitive agricultural production, marketing and processing. It was also assumed that food security would be attained other than formerly pursued food self-sufficiency under regulated market. The government was left with the technical advising and facilitation role. Unfortunately, reportedly the institutional and economic policy constraints have been market failures and weakness of private sector to develop because people have low skills' level, lack capital and united managerial capabilities. Lack of supply of critical services and inputs to support agricultural production, cause sustainable development and alleviate poverty in remote places where private traders find it uneconomic to invest due to economies of scale absence has resulted in at least $86 \%$ of the peasants untransformed and worse than before. The number of fallow fields has increased and food prices have sky rocketed. The role of technical advising and facilitation is counteracted by the same liberal policy contradiction for efficiency of labor downsizing ever-continuing (ASIP, 1997 and Lehohla, Lebusa, Lenka, Moteane, Lethunya and Mohau, 1993).

Although the economic impact of liberalization to the government has been savings in recurrent expenditure, revenue increment from rent and set field for competitive private sector, peasants' interests, needs, and their involvement have not been part of the process. They remain neglected since there are no mechanisms developed to channel or trickle down any such benefits from government. The government has benefited more and the poor are continuing to be poor. Industrial growth and its increase in demand for food supply have not been harnessed to maximize such an opportunity. More complications are that monopolies in service provision have been created hindering diversification in crops production. This promoted inappropriate maize production practices inducing soil degradation (ASIP, 1997 and GOL Technical Report, 1999). There is still some existence of subsidy for the benefit of these few privatized monopolies in the form of subsidized credits and government paid staff. Such monopoly subsidy is mostly prevalent in technical operations unit (TOU) for tractor hiring services and specialized farm services like animal and plant breeding, combine harvesting, delivery system and others. This confirms the statement that, "Small farmers have been adversely affected by the withdrawal of supports (SAPs) while some large scale farmers and (transnational corporations) TNCs continue to enjoy hidden subsidies (Ellis, 1998)". Therefore, further influence on prices continues disabling private sector growth. May be this could be on the justification of weak private sector but this stifles it further. Alternative means of continuing with the subsidy to benefit the poor with their involvement has not been sought. Instead, monopolies, which are usually blamed for not taking market price thereby determining prices, hamper perfect market competition. Large-scale mills for grain storage and supply still serve as main stations for selling of countrywide farmers' produce at fixed GOL controlled prices for either price stabilization or agricultural terms of trade favoring urban population and not necessarily to transform them from subsistence to sustainable agribusiness.

Effectually, large-scale mills have become monopolies determining and controlling prices through mill door and GOL declared prices not for the cost of production recovery by peasants, limiting diversification by determining which crops are marketable. This does not increase their income within this policy restrictions and contradictions in the 1995 declared liberalized market. National parity pricing severely disfavors farmers 
highly unequally because transport and other costs to these main price monopoly stations are not at par. While the genuine reason could be quality control through grading, illicit charges on farmers for quick service or favorable grade and waiting for payments may stifle market competition. In some cases, especially in Co-op Lesotho as was another major marketing outlet, social class and power determined which farmer may be served first and at which 'grade'. Logically, monopolistic market environment by large-scale mills and Co-op Lesotho contradict and constrain liberalization and perfect competition as they also ultimately determine panseasonal and pan-territorial pricing disproportionately benefiting peasants experiencing variant transport and input costs thereby creating spatial disparity and inequity. Perfect competition or liberalization and monopoly or monopsony may not logically co-exist (ASIP, 1997, Lehohla, Lebusa, Lenka, Moteane, Lethunya and Mohau, 1993, and FAO, 1987:105). Above analysis makes inference of diagram below;

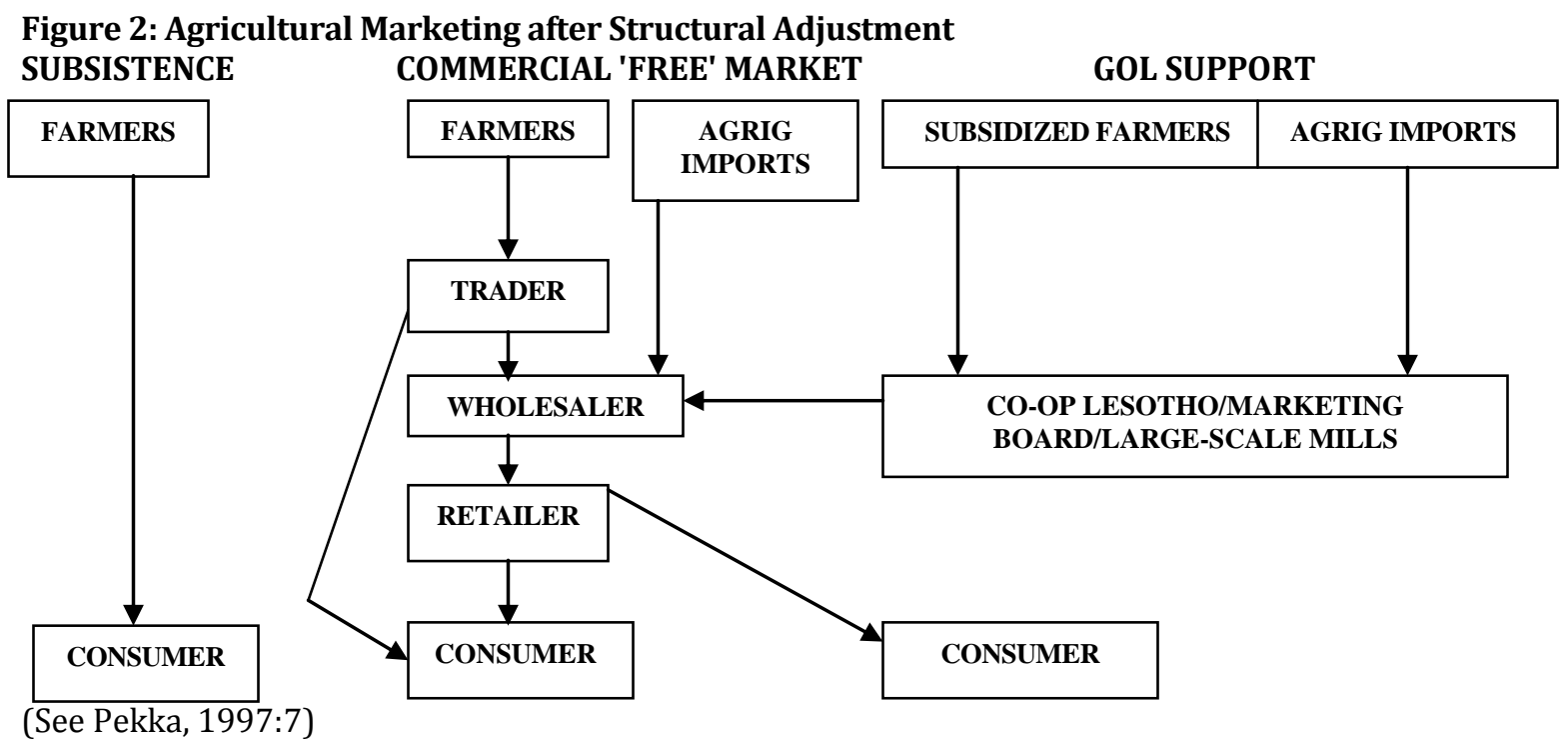

\section{Incidences since 1995, Liberalization Constraints and Implications}

The process of liberalization has now started in Lesotho since 1995. Government assets (machinery, building stores) used in subsidized input sale and distribution are being advertised for privatization. However, only already wealthier people are able to access and possess these assets. Although Co-op Lesotho is privatized as was revived from its downfall of 1993 through SAPs aid support, GOL is still a shareholder. Inputs and animal feeds have become of poor quality in large supplies across the country at unaffordable prices to peasants. Hybrids that made better returns are now rare and too expensive. The 'privatized' Co-op is able to do as such as it have no effective competitor countrywide. Hence, agricultural production has become $14 \%$ of GDP declining from former $30 \%$ to $40 \%$. Inputs supplying stores have become few and nonexistent in remote areas, those that are there are too expensive, usually out of stock taking long time to restock and lack input diversification. Timelines in input supply has become a constraint in production causing late planting. Peasants do not afford transport costs for afar town based input stores. There is more food aid needed than before and there are more food aid dependent programs than before as confirmed by GOL (1999 and 20002002) reports. Instead of food security there is heavy food aid dependency improperly rationed and often marked by striving, political biases and conflicts. The cost of this normal functioning of 'free' market is social unrest, high unprecedented livestock armed robbery, raiding and theft countrywide. Due to above reasons there has been agricultural decline since 1990s as table below confirms (ASIP, 1997).

Before market liberalization, GOL policies aimed at reducing dependence on food imports and protect domestic producers against unfair competition from subsidized RSA's farmers. Liberalized market opens up local production to such stiff unfair continuing competition resulting in undermining of local individual efforts. This external factor adds to internal stifling ones on individual private efforts and the only $14 \%$ surplus producers will decline further. Present crops marketing structure is such that Lesotho's most domestic production is for subsistence and some informal trade. Cereal deficits are met by import from world 
market. Two large-scale mills are still there, Lesotho Flour Mills (LFM) owning a wholesale, Lesotho Milling Company shared between GOL through Lesotho National Development Corporation and RSA's company Tiger Oats. Large-scale mills still receive farmers' produce for marketing, store more than 100,000 tons of maize and wheat, and due to their economies of scale in pursuit of food security suppress private producers and small-scale mills (See Mair and Miller, 1991). After liberalization, industrial mills still hold most of staple maize grain imports choking private local efforts at sales' level. Monopoly and monopsony created under liberalization that replaced state evil of minimum producer prices, maximum selling or mill door prices, panterritorial and pan-seasonal producer prices and import parity pricing above market prices by powerful institutions in 'free' market continue depriving poor ones of food accessibility, choking private local producers and small-scale mills at sales' level, service provision and employment creation (See ASIP, 1997 and ICA, 1985-1995).

Table 1: Lesotho Agricultural Contribution to GDP since 1990s

\begin{tabular}{llllllllll}
\hline SECTOR & SUBSECTO & $\mathbf{1 9 9}$ & $\mathbf{1 9 9}$ & $\mathbf{1 9 9}$ & $\mathbf{1 9 9 3}$ & $\mathbf{1 9 9 4}$ & $\mathbf{1 9 9 5}$ & $\mathbf{1 9 9 6}$ & $\mathbf{1 9 9 7}$ \\
& $\mathbf{R}$ & $\mathbf{0}$ & $\mathbf{1}$ & $\mathbf{2}$ & & & & & \\
\hline AGRICULTUR & & 17 & 11 & 9 & 13 & 14 & 11 & 14 & 13 \\
E TOTAL & & & & & & & & & \\
& LIVESTOCK & 6 & 7 & 4 & 7 & 7 & 7 & 7 & not \\
& $\begin{array}{l}\text { CROPS } \\
\text { SERVICES }\end{array}$ & 10 & 2 & 3 & 4 & 5 & 3 & 6 & $\begin{array}{l}\text { given } \\
\text { " }\end{array}$ \\
& & 2 & 1 & 1 & 1 & 1 & 1 & 43 \\
$\begin{array}{l}\text { SECONDARY } \\
\text { SECTOR }\end{array}$ & 42 & 37 & 36 & 36 & 37 & 39 & 41 & \\
$\begin{array}{l}\text { TERTIARY } \\
\text { SECTOR }\end{array}$ & 41 & 52 & 55 & 51 & 49 & 50 & 45 & \\
& 100 & 100 & 100 & 100 & 100 & 100 & 100 & 100 \\
\hline
\end{tabular}

(GOL Main Report, 1999)

Conflicting objectives hinder liberalized market since in crops sector GOL still owns farms for crops diversification strategy, experimentation, demonstration facility and seedling production for high value crops, though liberalization is adopted. Crops from government farms are not sold at commercial prices and stifle private sector price functioning and its development. This constrains economic viability of private producers. Marketing information system is still not well developed to cover quantities, location and commodity prices, market growth will be inhibited. Guaranteed market channels and stable prices farmers used to enjoy through Co-op and Large-scale mills are now nonexistent. Peasants have to face unstable volatile prices and powerless negotiating against powerful traders' exploitation (in fact most of the supermarkets retailing produce from local farmers are sole severe (buying) price setters and selling price givers for profit maximization) (ASIP, 1997 and Jayne, Mukumbu, Chisvo, Tschirley, Weber, Zulu, Johansson, Santos and Soroko.1999). Peasants no more have guaranteed transport, storing facilities, credit and input sources, many of them are held under grip of lacking. Particularly, lack of machinery, tractor distribution and access is skewed and concentrated in the very few hands as table below confirms. The 1995 market liberalization has not actually redistributed and changed this; instead, it worsened it because only six tractors still remained accessible per 1000 producers. Only the nominal figure of tractors increased from 47 to 63 concentrating in few hands whereby the already rich got richer and the poor remaining poorer because such machinery availability never transformed into accessibility as poor producers lacked cash to rent or buy such machinery, except for the already well off ones. Accessibility of agricultural machinery remained consistently poor never changing from the six producers per 1000 (World Development Indicators, 2000).

Table 2: Lesotho Machinery/Tractor Ownership and Distribution Pre and Post 1995 SAPs

\begin{tabular}{lll}
\hline Tractor Distribution & $\mathbf{1 9 8 0 - 9 0}$ & $\mathbf{1 9 9 0 - 9 8}$ \\
\hline Agricultural machinery/Tractors per 1000 workers & $6(1979-81)$ & $6(1995-97)$ \\
Tractors per 100 hectares of arable land & $47(1979-81)$ & $63(1995-97)$ \\
\hline
\end{tabular}

(World Development Indicators, 2000) 
Their risks are highly increased, those who try to continue remain profitless due to high input and transport costs worsened by lack of ready formal marketing channels replaced by retailers and wholesalers who lord prices, make them incur high unknown transaction and packaging costs. GOL institutions now compete with them severely at the level of production, marketing and processing. Obviously, privatization and nonprivatization in Lesotho have a problem of pare to optimum since equilibrium may not easily exist under these market circumstances. Now there are failures of competition, provision and insufficient markets, macro-economic problems such as inflation and monopolies, asymmetric market information, poverty and lack of sustainable development and social inequality. The obvious lack of political commitment on GOL, policy vacillation and treating liberalization as an abdication or short-run process lead to endless complications and ineffective liberalization (See Ellis, 1992, ASIP, 1997 and Jayne and Jones, 2010).

\section{Analytic Conclusions on Lesotho Agricultural Marketing Reforms and Constraints against Sustainable Development and Poverty Reduction}

Global and regional strategies to utilise comparative advantages in production for food security are lacking. One of institutional constraints to liberalized agricultural marketing could be communal land tenure demerit of allowing unregulated common open access promoting overgrazing that deteriorates rangeland. This type of liberalization limits livestock market supply and sustainability/sustainable development and poverty reduction. Though there is "Tragedy of Commons" problem, Basotho do not regard land tenure as a critical problem. They perceive problems to be improper grazing, land use, and institutional land administrative conflicts between chiefs with traditional powers and local councillors with political power striving for control over resources. Grassroots farmers associations legally empowered to manage resources for themselves could be most ideal and not an institution lacking felt needs and direct interest. Traditional social-political structures are not innovative enough and constrain liberalization. Associations could do better bearing direct interest. The fact is communal grazing leads to no accountability by users resulting in overstocking on rangeland preventing regrowth. This affects quality of wool and mohair and milk production. Liberalization adoption laid off some government livestock technical staff, remaining is too few to provide any effective technical support for quality breeding for market. They are also not decentralised at least according to farmers associations, instead they still make unimpactful seldom field trips. This policy framework is thus constrained by inadequate undecentralized trained manpower resulting in untrained peasants remaining attitudinally untransformed regarding keeping much unproductive livestock as store of wealth only for prestige and occasional traditional rituals/ceremonies (GOL, 1999, Green, 2000, Mashinini, 1982, Mashinini, and De Villiers, 2001 and Murray, 1981).

Agricultural productivity and marketing in Lesotho is reported to be constrained by RSA's economy. It is argued that peasants lack incentive to work on farm due to now rare supplement from migrant earnings from RSA. This could be true to some extent but in the face of high mineworkers' retrenchment due to technological advances and gold depreciation, this reasoning overlooks other internal and external issues. It is Basotho who are mostly managing immediately bordering RSA's farms to Lesotho, highly equipped with capital on land with the same climate as Lesotho's. Lesotho has technological policy constraint adversely affecting agricultural market supply, hence immediate alternative now, and scarce migrant employment. There is no profitable capital distributive contract farming. Some authors continue to argue that wives of migrants are already exhausted from house chores and have ample time for farming. This overlooks arguments like migrant earnings have been too low and exploitative compelling wives to adopt various means of survival livelihoods, let alone customary gender division of labour in agriculture requiring wives to hoe, weed, harvest, process and class pulses for marketing. Low returns to their labour due to lack of implements, inputs and combination of environmental factors like soil erosion, steep land topography and occasional drought are more direct constraints. If anything, migrant earnings enable them to access some agricultural implements and draft animals but insufficient for agricultural intensification considering tractorization concentrated in few hands in liberalization as shown in the table above. While it could be argued that male labour being migrant workers creates labour shortage in farming, that overlooks cyclic migration that allows them to come home every month and even nicknamed 'weekenders' or seasonal-comers particularly for ploughing and festive seasons. Liberalization in Lesotho is constrained by lack of economies of scale relative to global productivity, having to do with lacking capital, public, fiscal and physical infrastructure and indigenous self-organization (Setai, 1984, GOL, 1999, Brokken, Swallow, Motsamai and Mpemi, 1986 and Murray, 1981). 


\section{References}

ASIP Mission 2 Lesotho. (1997). Privatisation and Market Liberalisation. Maseru: Government of Lesotho Printing Unit.

Brokken, R. F., Brent, M. S., 'Mabaitsi, M. M. \& 'Malijeng, M. (1986). Marketing Grains, Pulses and Vegetables in Lesotho. Roma: National University of Lesotho.

Ellis, F. (1992). Agricultural Policies in Developing Countries. Great Britain: University Press, Cambridge.

Ellis, F. (1998). Household Strategies and Rural Livelihood Diversification. Journal of Development Studies, 35(1).

Food and Agriculture Organization. (1987). Agricultural Price Policies: Issues and Proposals. Rome: FAO.

Government of Lesotho. (1999). National Livestock Development Study. Phase 1 Technical Report M Part II. Maseru: Kingdom of Lesotho.

Green T. (2000). Indicators for Monitoring Changes of Livelihood Systems in the Mountains and Southern Districts of Lesotho: Working Papers Multiple livelihoods and Social Change. WP14. Manchester: University of Manchester.

International Co-operative Alliance. (1995). A Report on the ICA/FAO/ILO Inter-Agency Mission to Lesotho in Support of Co-operative Development. Maseru: Government Printing Unit.

Jayne, T. S., Mulinge, M., Munhamo, C., David, T., Weber, M. T., Zulu, B., Johansson, R., Santos, P. \& Soroko, D. (1999). Successes and Challenges of Food Market Reform: Experiences from Kenya, Mozambique, Zambia, and Zimbabwe. Michigan: MSU International Development Working Papers.

Jayne. T. S. \& Jones, S. (2010). Food Marketing and Pricing Policy in Eastern and Southern Africa: Lessons for Increasing Agricultural Productivity and Access to Food. http://www.aec.msu.edu./agecon/fs2/polsyn/no12.htm (Accessed on 12/01/14).

Lehohla, M. L., Lebusa, J. M., Lenka, T., Moteane, M., Lethunya, L. \& Mohau, K. (1993). Commission of Inquiry into Co-operatives. Maseru: Government Printing Unit/AIS.

Mair, D. \& Miller, A. G. (1991). A Modern Guide to Economic Thought: An Introduction to Comparative Schools Of Thought in Economics. England: Edward Elgar Publishing Company.

Mashinini, I. V. (1982). Land Tenure and Agricultural Development in Lesotho. The Hague: Institute of Social Studies.

Mashinini, V. \& De Villiers, G. (2001). Community Participation: Facilitation or Impairment of Sustainable Development. Africa Insight, 31(1).

Murray, C. (1981). Families Divided: The Impact of Migrant Labour in Lesotho. Johannesburg: Ravan Press (Pty) Ltd.

Pekka, S. (1997). Food Marketing Reconsidered: An Assessment of the Liberalization of Food Marketing in SubSaharan Africa. Helsinki: UNU/WIDER.

Setai, B. (1984). Economic Constraints to Rural Development in Lesotho. Maseru: Government Printing Unit.

World Bank. (2000). World Development Indicators. Washington: World Bank. 